\title{
Zhivaia Starina in 2015
}

\author{
Olga V. Belova \\ The Institute of Slavic Studies, Russian Academy of Sciences \\ Moscow, Russia
}

2015 was declared the Year of Literature in Russia, so that the periodical focused on the interrelation of the literary and oral traditions, the importance of written sources in the formation and existence of oral texts, the language of popular culture, and the role of the performer and the bearer of the tradition in its transmission and preservation (issues 3,4 ). In keeping with the celebration of the $70^{\text {th }}$ anniversary of victory in World War II, we focused on the theme of war in popular memory (issue 3). 2015 also saw the $25^{\text {th }}$ anniversary of the State Republican Centre of Russian Folklore. The Centre's activity in Russian folklore and traditional culture studies was covered in a section in issue 4. As usual, topics related to regional studies in folklore and ethnography, the study of living forms of folk culture, and the discussion of problems and future of the studies of "living antiquity" were featured as well.

Issue 1 opened with a section entitled "Time and Calendar in Popular Culture." T. A. Agapkina in her article, "Feast — idle time? (The Benefits of Violating Taboo)" addressed the problem of personification of the concept of "idleness" in popular rituals associated with specific calendar dates. The author "The Rakhmans' Easter in Podolia $\left(19^{\text {th }}-21^{\text {st }}\right.$ centuries $)$, " O. I. Shalak presented an analytical overview of the rituals associated with the regional celebration of the Easter cycle and traced the transformation of the tradition for two centuries in Ukraine. E. A. Samodelova's "Yuletide Christmas Carols of the Kaluga, Orel and Tula regions", introduced materials recorded in 1985 . The article by P. Khristov and E. V. Petrova, "One's Own' Holiday Calendar of Bulgarians in the Odessa Region and the Ukrainians of Sofia," shows how diaspora groups living in an urban environment manage to retain their identity through folk religious symbolism in the calendar.

The section "Beliefs and Rites" also addressed the calendar theme and the theme of time in vernacular culture. R. Sliužinskas, 
in "“The Jew' as a Shrovetide Mummer in Lithuania," characterized regional features of mumming characters representing ethnic neighbors and pointed out the main ethnic and cultural stereotypes basic to construction of the image of the "other" in the folk calendar. G. I. Lopatin's "Easter Customs and Traditions in the Gomel region," presented field materials from the collection of F. G. Shklyarov Vetka Museum of Old Belief and Byelorussian Traditions. The article by V. V. Zaporozhets, "Memorates about 'Inopportune Times"' was based on narratives about the evil eye, curses or unusual cases that occurred at times viewed in the folk tradition as "bad" or "odd."

A large section "Folklore and ethnography of the peoples of Russia" brought together articles on Karelian folk culture (M. V. Kundozerova. "Big oak: the mythologeme of the world tree in the Karelian runes"); Evenk folk culture (N. A. Mamontova, "The Khosun legends of the Ilimpeyan Evenks"); Mordovian folk culture (V. I. Rogachev, "The rite of bride abduction in Mordovia (based on the $19^{\text {th }}$ - early $20^{\text {th }}$ century materials"); Romani folk culture (N. V. Bessonov. "The brides of 'foreign blood' in the Gypsy camp"); V. N. Yanysheva, "Romany horror stories"); Tatar folk culture (I. A. Bessonov, "Folklore and rituals of Tartars in the town of Galich"); and Bashkir folk culture (G. R. Khusainova, "Chelyabinsk Bashkirs' folklore in its modern state").

The "Expeditions" section featured materials from the Ural region (E. V. Rychkova, "Folk Bible of the Old Believers in Ural region"); the Komi Republic (L. S. Lobanova, "Materials from the village Yortom, Udorsky district of the Komi Republic"); and the Lower Volga region (V. A. Shilkin, "Holiday Soroki in the Volgograd region"). The "Jubilees" section offered congratulations to $\mathrm{N}$. Yu. Danchenkova, an ethnomusicologist and one of the leading experts in the sphere of musical folklore.

In the Issue 2 the section "The game in folk culture" combined articles exploring different Russian folk games (M. V. Gavrilova, "'Subject of the action' and 'character' in Russian folk games of the $19^{\text {th }}$ - early $20^{\text {th }}$ century"); various regional forms of the folk games (V. Yu. Kolchev, S. V. Meshcheryakov, "The Folk game ryukhi in the town of Ostashkov of the Tver region"; V. A. Shilkin, 
"Children's games in the Volgograd region"; O. A. Choekha, "Children's games in the Aegean Sea islands"); the lexicon and terminology of games (G. I. Romaniy, "Regional city names in the children's games 'chain' ('boyars')"); and the geographical distribution of games (G. R. Shagapova, "Five stones").

The section "Russians in Latgale" is devoted to folklore and traditional culture of the Russian people living in poly-ethnic and heterodox environments. It includes articles and publications based on the field research materials in the south-eastern regions of Latvia in 2011-2014 and addresses oral history, folklore, and the traditional spiritual culture of long-time Russian residents of the Baltic States: "Expeditions in Latgale" (S. N. Amosova, S. I. Pogodina, M. V. Vyatchina); "Stories of the appearance of the Old Believers communities in Latgale" (M. V. Vyatchina, S. I. Pogodina); "Toponymic legends of Latgale" (M. B. Gecht, D. V. Tereshina); "AAlien faith': narratives about ethnic neighbors religion" (Yu. O. Andreeva).

This issue contains a new section, "Folklore in research centers," devoted to investigation, training and teaching, field research and publishing activities of Russian and international universities and research centers, where folk and traditional culture studies is a fundamental discipline. Zhivaia Starina intends to invite colleagues to address contemporary trends in folklore studies and new methods and approaches to the investigation of cultural heritage.

Our first contributors to this section were from the Department of Folklore at the Philological Department of Lomonosov Moscow State University. Included were articles by Ya. Yu. Solovyova ("Rites of the Easter period in the Kuibyshev district in Kaluga region"); T. V. Soboleva ("On the sixth we buried the cuckoo..."); A. A. Ivanova ("Rusalki joy on Dukhovskaya week..."); A. A. Ivanova, T. V. Soboleva ("On Ivan Kupala witches go breaking crops..."); and A. F. Balashova ("The world of the living and the world of the dead in the view of the seekers").

The section "Expeditions" contains materials from the Komi Republic (P. A. Shakhmatskaya, "Beliefs about domovoy [house spirit] in the mining settlements of the Komi Republic") and the 
Crimea (S. V. Alpatov, A. N. Voinik. "Crimean expedition of the Moscow State University in 2014"). The "Jubilees" section focused on M. P. Cherednikova, a specialist in children's folklore, in contemporary folklore, and in the traditional culture of the Ulyanovsk region (Middle Volga).

Issue 3 opened with a section "The War in people's memory", devoted to folklore samples which reflected the events of the World War II in the collective and individual memory (see also issues of Zhivaia Starina in connection with the anniversaries of World War II in 1995, No. 2; 2005, No. 2; 2010, No 2). The section contains Nikita Ilyich Tolstoy's letters from the front by (prepared for publication by S. M. Tolstaya). V. N. Sedykh published materials from the family archive ("The song helped us to survive and win") on the organization of the army song, dance and music ensembles. Several publications are devoted to oral personal narratives and memoirs: N. Yu. Danchenkova. "The memory of the war in the laments of M. A. Korolyova (Tatarovo village, Vladimir region)"; "Poetic memoirs by N. A. Vetrova" (a publication by M. V. Stroganov); "War narratives from the Selizharovsky district of the Tver region" (a publication by M. N. Tolstaya).

The section "The mythological locus in the folk tradition" reflected the diversity of genres in which the concept of space and the symbolism of locus play a role setting the scene; the ritual acts associated with specific places and locales were considered as well: D. V. Gromov. "Legends of the Galich lake"; M. V Akhmetova. "The legend of Sonya's grove (Bologoe, Tver region)"; G. I. Lopatin. "The holy springs in Vetka district, Gomel region"; I. Yu. Vasiliev. "The monuments of Krasnodar city in the residents' judgements and modern rites"; and K. E. Shumov. "Environment in beliefs of circus performers and sportsmen."

The articles in "Written sources and popular culture" are devoted to the interaction of written and oral forms of culture. In the article by A. G. Avdeev, "Inscriptions in the epic: stones on the crossroads (notes of an epigraphist)," the inscriptions mentioned in epic songs are analyzed in the context of medieval artifacts. D. A. Radchenko's article "Handwritten 'heavenly letters' in Russia of the $19^{\text {th }}$ century: 'letter from the Languedoc"' provides textual analysis 
of a manuscript from the middle of the $19^{\text {th }}$ century, a version of the so-called "heavenly letter" in comparison to other Russian and Western European counterparts. The article by S. N. Amosova, "Legend of the 12 Fridays in handwritten notebooks of Latgale," presents a classification of the apocryphal versions of this legend and contains a list of newly discovered variants. V. P. Ershov's "Apocryphal prayers from Karelia" introduces texts from a typewritten collection of apocryphal texts transferred in 1986 to the Karelian Museum for the history of religion. The article by M. V. Kalashnikova, "When the song isn't a song anymore: the genre transformation in albums and songbooks," is devoted to the existence and transformation of song genre in a new context.

The "Exhibition" section presented the materials from the exhibition "Clinking coin: Coins in traditional cultures of Eurasia" in the Russian Museum of Ethnography in St. Petersburg (authors of the publication are A. B. Ostrovsky and A. V. Ratnikova). "Expeditions" was centered on field research from Serbia, Montenegro and Bosnia (A. A. Plotnikova, "Traditions of the Orthodox and the Muslims on the borderlands of Serbia, Montenegro and Bosnia") and from the Mogilyov region of Belarus' (V. A. Kuhtina, N. A. Savina, "The expedition to the RussianByelorussian borderland").

Issue 4 was primarily devoted to the $25^{\text {th }}$ anniversary of the State Republican Center of Russian Folklore. The articles presented Center activity dedicated to the study, preservation and promotion of the folk tradition; on its coordination the work of folklorists in Russia and abroad; and its academic, publishing, archival, fieldwork, methodological and educational activities (V. E. Dobrovolskaya, "Scholarly-methodical and publishing activities of the Center of Russian folklore"; D. V. Morozov, "Field research and archival work of the Center of Russian folklore"; A. B. Ippolitova, "Northern Russian herbals of $17^{\text {th }}$ century"; V. E. Dobrovolskaya, "Copybook with folk tales of the Bryansk province"; E. G. Boronina, "The Whitsunday rite of bypassing the yards in the East of Moscow region"; A. G. Kuleshov, "Alexey Ivanovich Denshin and the revival of Dymkovo toy handycraft"; M. V. Stroganov, "Death and fate in heartbreaking romance (on the materials of the 
Tver region)."

The section "Language of folk culture" is devoted to the existence of the word in vernacular culture, to the verbal code of culture, to characteristics of the language of folk genres, and to the theoretical aspects of folklore. In the article "Speech acts and speech genres in folklore," S. M. Tolstaya examines the boundaries between the speech genres in spontaneous speech and folklore, the correlation of the content of a folk text content and the context of its existence, and the spectrum of proverbial pragmatic functions. A number of articles are devoted to folk phraseology, argot, proverbs and sayings: "What is a 'blind rain'?" by L. N. Vinogradova; "Why a woman is a 'husk', or Russian skalds on the banks of Vitim river" by A. V. Korovashko; "Podarish went to Paris: The Russian proverb in the European context" by S. V. Alpatov; "Verbal magic of folk gardening in East Slavic tradition" by N. A. Savina.

In the section "Personality — repertoire — text" the researchers focused on the problems of individual performance, the individual's role in preserving and enriching the folk tradition. Materials featured include those from the Kirov region (L. V. Fadeeva, "Legends, memorates and fabulates by Nina Dmitrievna Penkina"); the Gomel region of Belarus (the publication by G. I. Lopatin, "Spells from Ekaterina Evdokimovna Chueshkova's notebooks"); and the Perm region (S. Yu. Korolyova, "The naïve prose by Ivan Fedoseyev"; I. S. Fedoseyev. "Once there was my village...").

The field work section included materials from the Komi Republic (publication by T. S. Kaneva and D. I. Shomysov, "Yavlennaia Bogoroditsa [miraculous appearance of Our Lady icon] in Nonburg village (Komi Republic)." "Jubilees" honored A. N. Vlasov, a researcher of folklore and literature and a leading specialist in regional folklore studies. "In Memoriam" was dedicated to Mikhail Aleksandrovich Lobanov (1943-2015), musicologist and enthusiastic researcher of epic poetry (the author of the publication is V. A. Lapin).

Zhivaia Starina also published 17 reviews of monographs and edited volumes on folklore, ethnography and anthropology (14 reviews devoted to the Russian publications and three to international ones) and 13 chronicle articles. 